\title{
Les Tirailleurs sénégalais
}

For much of the past century, packets of the popular Banania powdered chocolate drink have been adorned with the image of a cartoonish, wide-eyed, smiling tirailleur sénégalais [colonial infantryman]. Withdrawn in the era of decolonization, the smiling tirailleur returned to the product's packaging in 2003: the image still had currency in contemporary France and the ideas sustaining it were very much still alive, albeit in new and complex forms. ${ }^{1}$ This image is arguably the most important site of French colonial memory, even though many French people today would have difficulty explaining who exactly the tirailleurs sénégalais were: advertising has long been a powerful and insidious method through which racialized types can be propagated and normalized (Bachollet, 1992). Mireille Rosello describes the Banania image as 'an unforgettable cultural icon branded with the same intensity into the minds of white and black French [...] people' (1998: 5). The Banania soldier utters his pidgin French slogan 'Y a bon', which is often translated into English as 'sho' good'. It is significant that translators have searched for an equivalent in the lexicon of the deep south of the United States of America, as the image can readily be situated within the racial imaginary that informed minstrel shows and other forms of caricatured black 'comic' performance. The racialized thinking encoded within the image was all too visible to colonial subjects of the mid-twentieth century. In one of the best-known passages from Peau noire, masques blancs, Frantz Fanon identified ' $\mathrm{Y}$ a bon Banania' as the most pernicious of the stereotypes discernible in the child's fearful gaze upon him as a black man (1952: 90). Even Léopold Sédar Senghor, the great poet of Negritude, whose writing and politics consistently sought to overcome the divide between colonizer and colonized angrily declared in his 'Poème liminaire' (first published in 1948), that 'Je déchirerai les rires Banania sur tous

\footnotetext{
${ }^{1}$ For a detailed analysis of Banania advertisements over the past century, see Achille (2013).
} 
les murs de France' [I will tear down the Banania smiles from every wall in France] (Senghor, 2006: 55).

The continued use of both image and slogan today — not just on the product packaging for Banania, but on postcards, posters, plates and other forms of memorabilia readily available in virtually every tourist shop in Paris - may seem at first glance to denote a form of postmodern pastiche. However, the ways in which both word and text have in recent times been used with little need for transformation in order to create vicious racist memes circulating on the internet about black public figures, not least (at the time of writing) the former French Justice Minister, Christiane Taubira, a black woman from French Guiana, indicates clearly that familiarity may have dulled their racially charged nature but it clearly has not erased it. As Anne Donadey argued in a seminal article on Banania almost two decades ago: 'To show colonial stereotypes without providing an explicit critique of these images ultimately reinforces the former colonizer's sense of subjectivity and negates the subjectivity of former colonized peoples' (2000: 17).

\section{From the origins of the tirailleurs to the First World War}

The first tirailleur sénégalais regiments were formed in 1857. They took their name from the original location where they were founded, but would in fact go on to play a key role in the conquest of France's vast West African empire. ${ }^{2}$ Serving the imperial project, the tirailleurs quickly became associated with the excess and the arbitrary nature of colonial violence. With the advent of the First World War, however, the tirailleur would become inextricably linked to the story of metropolitan France. Indeed, in the aftermath of the war the tirailleur sénégalais became an iconic figure in France: his familiar face and colourful uniform -in

\footnotetext{
${ }^{2}$ For a comprehensive history of the tirailleurs, see Echenberg (1991). Fogarty (2008) focuses more specifically on the tirailleurs and the two world wars.
} 
particular, the bright red chechia hat — featured in drawings, postcards, photographs, posters and other material. As the Banania imagery demonstrates so powerfully, the war saw the tirailleur transformed from savage, colonized other into brave, smiling warrior fighting to defend the imperial homeland.

The First World War constituted a major watershed in race relations in the Hexagon (Stovall, 2003): during the war, the French authorities brought over half a million soldiers and labourers to the Metropole from its colonies as well as from China. ${ }^{3}$ Over 200,000 subSaharan African troops were raised during the war while approximately 130,000 saw active service in France with 34,000 killed, many in the latter stages of the conflict from 1916 onwards (Michel, 2003). There is considerable evidence that the tirailleurs were often used as shock troops in that later period when, some historians believe, they were deployed more widely with the unstated aim of sparing white French lives.

The bravery shown by the tirailleurs sénégalais in landmark battles at Verdun and elsewhere, as well as the direct human contact between ordinary French people (soldiers and civilians) and tirailleurs stationed in France, soon led to a proliferation of images that has no real equivalent in representations of other sections of the colonial army. The tirailleur found his place in the gallery of French military 'types' in official and unofficial military propaganda. Previous images of the savage tirailleur were recycled as celebrations of the mighty warrior fighting on 'our' side. Now that the tirailleur was a real person whom one might meet in the streets of Paris or Lyon or even provincial France, there also emerged series of portraits designed to express his humanity. Perhaps most importantly, in place of the

\footnotetext{
${ }^{3}$ The idea of countering Germany's demographic advantage over France, through the creation of an African army drawn from France's colonies to fight in an anticipated European war, had first been developed by General Charles Mangin in his 1910 volume, La Force noire.
} 
previously dominant image of the bloodthirsty tirailleur, the image spread of the tirailleur as a 'big child' who smilingly served France, most infamously in the imagery for Banania but present also, for example, in a wide range of postcards of the period: a common visual trope depicted a smiling, barefoot tirailleur cheerfully charging towards a cowering German soldier. In addition, the period after the war witnessed a proliferation of popular literary representations, both fictional and non-fictional. ${ }^{4}$ The tirailleur had become an instantly recognizable feature of French culture and society.

In their volume, 14-18: Vivre et mourir dans les tranchées, historians Rémy Cazals and André Loez trace the diverse reactions of ordinary French soldiers to the experience of fighting alongside black troops: "The perception of these [colonial soldiers] oscillates between that of the brother in arms and that of the colonizer. The expression of solidarity stands alongside expressions of curiosity or contempt' (2012: 169). Some French troops were almost as fearful of the 'savagery' of their colonized allies as they were of their German enemies —noting their alleged predilection for cutting 'trophies' from the bodies of fallen enemies (169) — while others expressed a mix of curiosity and empathy for these men torn from their West African homeland and obliged to fight in the muddy trenches of northern France/Belgium (170). One of the most valuable sources that we possess regarding the preoccupations and attitudes of tirailleurs sénégalais during the war is Lucie Cousturier's memoir, Des inconnus chez moi, first published in 1920. Cousturier, a minor impressionist painter, knew little about colonialism or Africa until, in the spring of 1916, the French army chose to develop its main metropolitan base for the tirailleurs on the doorstep of her country

\footnotetext{
${ }^{4}$ Two of the best-known examples are La Randonnée de Samba Diouf (1926) by the bestselling popular authors, the Tharaud brothers, and the very successful episodic novel by Raymond Escholier, based on one of the tirailleurs he encountered, the eponymous
} Mahmadou Fofana (1928). 
retreat in the small Mediterranean town of Fréjus. The town had previously housed a minor base but, from 1916 until the end of the war, the tirailleurs were sent there for the duration of the winter, as although sub-Saharan African soldiers were generally deemed 'natural' warriors, the French army considered that they were unsuited to the rigours of winter warfare in Europe. Initially fearful of these 'strangers', Cousturier soon turned her home into an informal school where she taught the largely illiterate soldiers basic literacy in French.

Cousturier was in effect playing a variation on the role of a marraine de guerre ('war godmother'): marraines were young or middle-aged French women who had volunteered to correspond with soldiers in the French army, including tirailleurs, acting as surrogate sisters or mothers, and some would take these young African men under their wings during periods of leave. However, partnering French women with young African men inevitably led in some instances to more intimate relationships than had been envisaged by either the Church or the Army, and support for the scheme quickly cooled. As the war progressed, a more general fear developed regarding the interaction of colonial men and French women. Colonial troops on leave from the front line could socialize with French women, while in the factories, women occupying industrial posts in the absence of conscripted French men often worked alongside imported labour from l'Indochine française. With very few black women on French soil at that time, interracial relationships became an inevitable emotional and sexual reality. ${ }^{5}$ The offspring from these relationships is perhaps the most tangible but neglected legacy of the tirailleurs' time in France.

\section{The Interwar Period and the Second World War}

While the vast majority of tirailleurs (and other colonial troops and workers) were quickly repatriated after the war, a small number remained in France, joining the ranks of the urban

\footnotetext{
${ }^{5}$ For more on the sexual politics surrounding the tirailleurs, see Stovall (2003).
} 
working-class in Paris and major port towns such as Marseille, Bordeaux and Le Havre. In addition, the camp that had been built in Fréjus remained open and, all through the interwar period, thousands of tirailleurs were consistently based there: indeed, if there is one key geographical site of memory of the tirailleur sénégalais in France, then it is Fréjus. As historian Gregory Mann has argued, 'by 1918, Fréjus was both an African site and a truly “colonial" one' (2005: 434). Recent research has uncovered the history of Afrique-sur-Seine but scholars have only scratched the surface of this 'Africa on the Riviera'.

The tirailleurs thus remained a visible presence in Europe during the interwar period and they continued to play a significant role in the highly charged military and political situation. Throughout the early 1920s, the French forces occupying the Rhineland were primarily drawn from the Colonial Army, including a large contingent of tirailleurs sénégalais, led by General Charles Mangin. This led to a wave of far-right German propaganda denouncing the 'black shame' of African troops occupying a European nation, accompanied by claims of widespread rape of German women. Although vigorously denied by the military and civil authorities of the victorious Allied nations, this extremist propaganda found echoes in the press and amongst some politicians in France and Britain.

German 'revenge' for the 'black shame' arrived soon after the Fall of France in the summer of 1940. The German army entered Paris on 14 June 1940 and, just two days later, they destroyed (on Hitler's personal orders) a statue of Mangin, which had stood close to the Ecole Militaire, since 1928. For Hitler, Mangin represented the 'savagery' of a France willing to unleash its 'barbaric' colonial troops against white, European soldiers, actions compounded by the 'black shame' of the Rhineland occupation. A monument to the 'Heroes of the Black Army' in Reims, a city defended by the tirailleurs against a German onslaught in 1918, was also destroyed by the Nazis in September 1940. The destruction of these memorials sought to efface visible traces of the tirailleurs from the public realm in France, 
while other acts of violence constituted a far more brutal revenge against them. As French troops were captured by the advancing German army, there are many recorded instances where tirailleurs were taken aside and summarily executed: it is estimated that $1,500-2,000$ tirailleurs were killed in this fashion. While captured metropolitan French troops were imprisoned in Germany, colonial soldiers were sent to Frontstalags in occupied France: by early 1941, there were 70,000 colonial troops in 22 Frontstalags across the occupied north of the country and some remained imprisoned there until the liberation. The historian Armelle Mabon has traced the close relationships that were forged between colonial soldiers and the local communities around the camps — for example, the marraine de guerre system was dusted down and used to maintain the morale of the soldiers - and she identifies the 'persistence of the memory' (96) of the tirailleurs in these areas.

As had occurred after the First World War, the French authorities sought after the liberation to remove the tirailleurs from metropolitan France as soon as possible and they were once again subjected to discriminatory treatment as regards pensions and money owed for their time spent in captivity. This discrimination led to the traumatic events at the Thiaroye demobilization camp outside Dakar when at least 35 tirailleurs sénégalais were massacred by the colonial army: in the military cover-up that followed, the massacre was presented as the suppression of a mutiny rather than legitimate protests demanding equal treatment. Recent research by Mabon indicates that the number of tirailleurs killed in this incident is almost definitely far higher than earlier estimates had allowed (the number could be as many as $300-400$ ). In December 2014 , on the $70^{\text {th }}$ anniversary of the massacre, then French President François Hollande symbolically 'returned' French archives on the events at Thiaroye to the Senegalese government. Although this gesture appeared to offer the full truth behind the events, the documents released were already known to scholars and they failed to reveal the site of the mass grave where they are buried. Thiaroye thus remains to this day an 
extremely powerful site of colonial memory, encapsulating so much of the troubled relationship between France and its colonial troops. ${ }^{6}$

\section{Conclusion}

In France's wars of decolonization that followed the Second World War — not least in French Indochina and Algeria - the tirailleurs continued to serve the empire and they did so right up until the wave of independences across Francophone Africa in 1960. The remaining African troops serving in the French Army were transferred, in 1964, to a single African battalion at the base in Fréjus from where they were discharged and returned to their newly independent homelands. Francophone African countries continue to send prospective army officers to France for training, and the area around Fréjus is still home to several military bases that regularly receive African soldiers. As in so many other areas of French life, the formal end of empire constituted less a rupture with the past than a change in the specific shape and form of practices that had endured for decades and sometimes centuries.

The centenary of the First World War has led to various projects commemorating the role of the tirailleurs sénégalais in the defence of France: from bandes dessinées to exhibitions to television series. African troops returned to the streets of Paris in 2010 when 13 Francophone African countries responded positively to President Sarkozy's invitation for them to open France's annual Bastille Day military parade to mark the $50^{\text {th }}$ anniversary of their independence. This French recognition of the African military contribution on behalf of France was celebrated in some quarters but decried in others where it was seen as sign of the ongoing imbalance in power relations between the two parties. A monument to the Heroes of the Black Army was unveiled in Fréjus in 1994 to mark the 50 ${ }^{\text {th }}$ anniversary of the Provence

\footnotetext{
${ }^{6}$ Thiaroye was not the only incident of this kind to emerge from the Second World War: see, for example, the 1946 Cayenne revolt (Alexandre, 1995).
} 
landings in which colonial troops played a central role, while the monument to the tirailleurs in Reims, which had been destroyed by the Nazis, was replaced by a new, more modest monument in 1960, before a bronze copy of the original imposing granite edifice was commissioned in time for the centenary of the Great War and officially inaugurated by President Macron in November 2018. Although these official sites of memory to the tirailleurs across the Hexagon signal a form of commemoration fostered by the state, in which equality is the leitmotif, it is the smiling face of Banania that remains the most powerful lieu de mémoire: its re-emergence in 2003 and continued popularity today reinforce Donadey's warning almost two decades ago that we are still living '[i]n a postcolonial context ripe with French colonial nostalgia' (29).

\section{David Murphy}

\section{Works Cited}

Achille, Etienne. 2013. 'A l'approche des cent ans de Banania, le retour du tirailleur'. Contemporary French Civilization 38, no. 2: 201-16.

Alexandre, Raphaël. 1995. La Révolte des tirailleurs sénégalais à Cayenne: 24-25 février 1946. Paris: L’Harmattan.

Bachollet, Raymond, et al. 1992. Négripub: l'image des noirs dans la publicité. Paris: Somogy.

Cazals, Rémy, and André Loez. 2012. 14-18: Vivre et mourir dans les tranchées. Paris: Tallandier.

Cousturier, Lucie. 2001 [1920]. Des inconnus chez moi. Edited by Roger Little. Paris: L’Harmattan. Collection 'Autrement mêmes'.

Donadey, Anne. 2000. "“Y' a bon Banania”: ethics and cultural criticism in the colonial context'. French Cultural Studies 11, no. 1: 9-29. 
Echenberg, Myron J. 1991. Colonial Conscripts: The 'Tirailleurs Sénégalais' in French West Africa, 1857-1960. Oxford: James Currey; Portsmouth: Heinemann.

Escholier, Raymond. 2013 [1928]. Mahmadou Fofana. Paris: L’Harmattan. Collection 'Autrement mêmes'.

Fanon, Frantz. 1952. Peau noire, masques blancs. Paris: Seuil.

Fogarty, Richard S. 2008. Race and War in France: Colonial Subjects in the French Army, 1914-1918. Baltimore: The Johns Hopkins University Press.

Mabon, Armelle. 2010. Prisonniers de guerre 'indigènes': visages oubliés de la France occupée. Paris: La Découverte.

Mangin, Charles. 2011 [1910]. La Force noire. Edited by Antoine Champeaux. Paris: L’Harmattan. Collection 'Autrement Mêmes'.

Mann, Gregory. 2005. 'Locating Colonial Histories: between Africa and France'. American Historical Review 110, no. 2: 409-34.

Michel, Marc. 2003. Les Africains et la grande guerre: l'appel à l'Afrique (1914-1918). Paris: Karthala.

Rosello, Mireille. 1998. Declining the Stereotype: Ethnicity and Representation in French Cultures. Hanover and London: University Press of New England.

Senghor, Léopold Sédar. 2006 [1948]. Euvre Poétique. Paris: Seuil.

Stovall, Tyler. 2003. 'Love, Labor and Race: Colonial Men and White Women in France during the Great War'. In French Civilization and its Discontents: Nationalism, Colonialism, Race, edited by Tyler Stovall and Georges van den Abbeele, 297-31. Lanham: Lexington.

Tharaud, Jean, and Jerôme Tharaud. 1922. La Randonnée de Samba Diouf. Paris: Plon. 